UDC 614.7(477):[502.22+504.61](043)

DOI https://doi.org/10.32846/2306-9716/2020.eco.3-30.7

\title{
FUNCTIONAL AND ECOLOGICAL EXPERTISE (FEE) IN CHECHELNYK DISTRICT, VINNYTSIA REGION
}

\author{
Yermishev O.V. \\ Vasyl' Stus Donetsk National University \\ 16, Yunosti Av., 21030, Vinnytsia \\ o.yermishev@donnu.edu.ua
}

\begin{abstract}
The concept of functional and ecological inspection (FEE) of radiation control regions developed by us fundamentally complements the accepted forms of dosimetric and thyroid dosimetric control. The purpose of our work was to carry out the verification of radiation dependence of functional health and dosimetric certification of settlements in Chechelnyk district of Vinnitsa region with the help of FEE. 1382 children (671 boys, 711 girls) of all ages living in the villages Bondurivka, Katashyn, Rogizka, Chervona Grebliya and town Chechelnyk in Chechelnytsk district during 1993-1996 were examined with the help of FVD method by V.G. Makats. The functional health of child population, which is becoming a "bioindicator" of individual health and characterizing the environmental dynamics of the compact living area, is in the focus of FEE attention. The ecological criterion of FEE of a particular region of the population is systemically dependent comparison of inhibition of functional activity of the organism (parasympathetic activity (PA), vegetative equilibrium (VE) and sympathetic activity (SA)). An integral characteristic of the ecological state is formed and the levels (zones) of its ecological pressure are determined on this basis. The surveyed populated areas of Bondurivka village, Katashyn village, Rogizka village, Chervona Grebliya village and the town Chechelnyk of Chechelnyk district in Vinnytsia region belong to the IV radiation control zone. Our observations have shown that functional and vegetative health of children is ecologically dependent and its indicators are the most sensitive bioindicators of radiation (environmental) pollution. Functional vegetative health of children in the surveyed populated areas of Chechelnyk district coincides with the official dosimetric certification of these areas. Monitoring of vegetative health of children should become the basis of modern functional medical examination of pediatric population and supplement state dosimetric and thyroid dosimetric certification of the populated areas. Key words: functional ecological inspection, ecological certification, functional health.
\end{abstract}

Функціонально-екологічна експертиза (ФЕЕ) Чечельницького району Вінницької області. Єрмішев О.В.

Розроблена концепція функціонально-екологічної експертизи регіонів радіаційного контролю принципово доповнює прийняті форми дозиметричного й тиреодозиметричного контролю. Метою роботи стало за допомогою функціональноекологічної експертизи провести верифікацію радіаційної залежності функціонального здоров'я та дозиметричної паспортизації населених пунктів Чечельницького району Вінницької області. За допомогою функціонально-вегетативної діагностики за методом В.Г. Макаца нами було обстежено 1382 дитини різного віку, що проживають у с. Бандурівка, с. Каташин, с. Рогізка, с. Червона гребля та смт Чечельник Чечельницького району протягом 1993-1996 років, 3 яких 671 хлопця та 711 дівчат. У центрі уваги функціонально-екологічної експертизи є функціональне здоров'я дитячого населення, яке стає «біоіндикатором» індивідуального здоров'я та характеризує екологічну динаміку в регіоні компактного проживання. Екологічним критерієм функціонально-екологічної експертизи конкретного регіону проживання населення $\epsilon$ системно залежне зіставлення пригнічення функціональної активності організму (парасимпатичної активності, вегетативної рівноваги й симпатичної активності). На цій основі формується інтегральна характеристика екологічного стану й визначаються рівні (зони) його екологічного тиску. Обстежені населені пункти - с. Бандурівка, с. Каташин, с. Рогізка, с. Червона гребля та смт Чечельник Чечельницького району Вінницької області - належать до IV зони радіаційного контролю. Наші спостереження довели, що функціонально-вегетативне здоров'я дітей екологічно залежне, а його показники $є$ найчутливішими біоіндикаторами радіаційного (екологічного) забруднення. Функціонально-вегетативне здоров'я дітей обстежених населених пунктів Чечельницького району збігаються з офіційною дозиметричною паспортизацією населених пунктів. Моніторинг вегетативного здоров’я дітей має стати основою сучасної функціональної диспансеризації дитячого населення та доповнювати державну дозиметричну й тиреодозиметричну паспортизацію населених пунктів. Ключові слова: функціонально-екологічна експертиза, екологічна паспортизація, функціональне здоров'я.

Problem statement. The growing anthropogenic impact on the environment, its pollution with various wastes of production, along with the overuse of natural resources it leads to the gradual degradation of the natural environment under the influence of negative anthropogenic factors. In modern conditions the speed of scientific and technological progress exceeds the magnitude the adaptive capacity of existing living organisms, including humans [2;9]. Transport, industry, energy and agriculture have the largest anthropogenic impact on the environment of Ukraine. All above mentioned factors adversely affect the environmental situation in
Ukraine and cause such negative effects as the greenhouse effect, acid rain and the destruction of the ozone layer. The main environmental problems for Ukraine at the present stage of development are radioactive contamination of territories, degradation of agricultural land, pollution of drinking water, destruction of forests and green spaces, accumulation of domestic and industrial waste, air pollution, etc. $[2 ; 9 ; 10]$.

Nowadays in Ukraine the part of relatively clean territories of the state is $7 \%$; conditionally pure $-8 \%$; low pollution $-15 \%$; human life-threatening one $-70 \%$, $1.7 \%$ of which are recognized as environmental disaster 
areas. Man made activity is contrary to nature today. About $30 \%$ of general diseases of the population are caused by environmental pollution and, thus, are ecologically dependent.

The relevance of research. Today, radioactive contamination is one of the greatest dangers for the population of Ukraine. The level of such contamination is the only state-controlled at the legislative level environmental-anthropogenic factor of negative impact on the human body. The concept of functional and ecological expertise (FEE) developed by us of the regions of radiation control of Ukraine confirms the expediency of state attention to the problem of "Ecological certification of children's population" (Prof. V.G. Makats) and fundamentally complements the accepted forms of dosimetric and thyroid dosimetric control $[2 ; 9]$.

The aim of our work is to carry out the verification of radiation dependence of functional health and dosimetric certification of settlements of the Chechelnyk district in Vinnytsia region with the help of FEE.

Relation of author's rework with important scientific and practical tasks. The scientific research work is a part of the state program "A two-stage system of rehabilitation of vegetative disorders in children living in the radiation control zone of Ukraine" (performed on behalf of the CM of Ukraine dated 01.06.1999 № 12010/87).

Analysis of recent research and publications. The main subject of the study of functional and ecological examination (FEE) method in the regions of radiation control of Ukraine is the complex state of the autonomic nervous system (ANS) of the child's organism as well as the analysis of the processes that affect it. The autonomic nervous system regulates all internal processes in the body and performs the regulation of metabolism in relation to environmental conditions as an adaptive-trophic function $[4 ; 5 ; 8]$.

There are many methods of investigating individual indicators of the autonomic nervous system, but most of them are unreliable due to their low repeatability (repeated results do not match the previous ones). The functional-vegetative diagnostics (FVD) of the autonomic health of the population by the method of V. Makats does not have such disadvantages, which allows to reveal the dispersion of vegetative levels that act as integral bioindicators of internal homeostasis and its dependence on environmental conditions. On this basis an integral characteristic of the ecological state is formed and the levels (zones) of its ecological pressure are determined. Functional health of the population reflects the ecological changes of the territory more objectively as it characterizes the ability of the body to adapt to the changing conditions of the external and internal environment [3].

Materials and methods. The correlations between changes in electrical conductivity of 24 representative FAZ (characterizing the state of the meridian as a unity) and the state of classical acupuncture meridi- ans "determining" the functional state of their respective internal organs and systems of the organism are used for the diagnosis. 1382 children (671 boys, 711 girls) of all ages living in the villages Bondurivka, Katashyn, Rogizka, Chervona Grebliy and urban village Chechelnyk of Chechelnytskyi district during 19931996 were examined with the help of the functional-vegetative diagnostics (FVD) according to the method of V. Makats. FVD was conducted in the morning (10:00-12:00). The bioelectric activity of 12 symmetric pairs of functionally active skin zones (24 FAZ), 12 on the hands and 12 on the feet, which reflect the functional activity of the sympathetic and parasympathetic nervous systems, was studied [5; 8]. The FVD according to the method of V. Makats and devices for its implementation were officially approved by the Ministry of Health of Ukraine "New Medical Equipment and New Methods of Diagnosis” (№ 5 from 25.12.91; № 1.08-01 from 11.01.94) and the Scientific Council of the Ministry of Health of Ukraine (No. 1.08-01 of 11/01/94).

A VITA $01 \mathrm{M}$ device is used for FVD, the voltage in the closed circuit of which does not exceed the levels of membrane potentials (1-5 $\mu \mathrm{A} ; 0.03-0.6 \mathrm{~V})$. The device does not require external energy sources for its operation. It has 2 diagnostic electrodes, a base electrode acceptor of electrons (AE) - a convex plate of a special alloy, pre-coated with an oxide film $(5 \times 7 \mathrm{~cm})$ and 2 paired diagnostic electrodes (DE - electron donors) in the form of a silvered pair, which are located in ebonite cups with a diameter of $1 \mathrm{~cm}$ and wrapped with foam gaskets. The base electrode (AE) is fixed by a special belt through a moist pad (moistened with saline solution) in the umbilical region (central mesogastric area (0-zone)) with medium density tension to create stable examination conditions. Diagnostic electrodes (DE) are also moistened with saline solution. The procedure is performed in the orthostatic position of a person. In the process of testing electrodes, DE are placed at right angles with a slight pressure (at the touch level), simultaneously are contacted with each pair of symmetric FAZ (left-right at each extremity) for 1-4 seconds to obtain stable performance in micro amperes. Electrodes are remoistened with saline solution after every 3 contacts with the FAZ. Obtained in $\mathrm{mA}$ data of FVD are transformed into relative values. The obtained data are compared with the norm and it is concluded about the degree of deviation from it and the level of functional health impairment [8]. Mathematical and statistical processing of the results of the observations was carried out using the method of nonparametric statistics proposed by E.A. Derevyanko to determine the magnitude of the shift of the function under the study [9].

The presentation of the main material. Vinnytsia region is one of the comprehensively developed agro-industrial and cultural-historical regions of Ukraine. The territory is 26.5 thousand $\mathrm{km}^{2}$, which is $4.4 \%$ of the area of Ukraine. The population is 1.61 million, $(3.75 \%$ of the country's population), including urban $50.6 \%$ 
and rural $49.4 \%$. The major problems of the region are caused by the following factors: a large amount of pollutant emissions into the atmosphere, the presence of the materials that are banned and unsuitable for plant protection as well as chemical production waste which have been accumulated over the past years, the lack of a proper system for collecting, sorting and disposing of household waste, the discharge of contaminated wastewater into water and terrain, high levels of land plowing and erosion.

Chechelnyk district is the district of Ukraine in the southeast of Vinnytsia region. The population is 22.6 thousand people, $1.4 \%$ of the population of the region (01.01.2018). The district includes the town of Chechelnyk (district center) and 21 rural settlements. 8 villages of these settlements suffered from the radiation contamination as a result of the Chernobyl accident. The area of the district is $759 \mathrm{~km}^{2}$, which is $2.9 \%$ of the region's territory.

The focus of the FEE should be on the functional health of particular age groups in the pediatric population which becomes a "bioindicator" of individual health and characterizes the environmental dynamics of the compact habitat region. Functional health levels have been found to be specific markers of the state of adaptation of the organism to the changing conditions of the external and internal environments and reflect the general functional and vegetative homeostasis of the human body. The obtained data on the functional health status of the pediatric population of a certain territory and averaged information on disorders of the autonomic nervous system can be used to analyze the impact of integrated environmental pressure on the human body, possible environmental problems of the territory and the degree of environmental impact. Nowadays, there is an understanding of adaptive dependence on the dynamic constancy of functional-vegetative homeostasis. The dependence of the individual-functional health of a child on the environment is supposed to be the basis of endoecology. The ecological criterion of FEE of a particular region of the population is a systemically dependent comparison of inhibition of functional activity of the organism (parasympathetic activity (PA), vegetative equilibrium (VE) and sympathetic activity (CA). On this basis an integral characteristic of the ecological state is formed and the levels (zones) of its ecological pressure are determined. FEE criteria should be consistent with the levels of radionuclide (environmental) contamination in the monitored observation regions of the Chechelnyk district in Vinnytsia region.

The sympathetic orientation of the autonomic nervous system (ANS) is known to be responsible for the FS of the following: the bladder (BL), the gall bladder (GB), the stomach (ST), the small intestine (SI), the lymphatic system (TE) as well as the large intestine (LI). The parasympathetic orientation of the ANS is responsible for FS of the spleen and pancreas (SP), the liver (LR), the kidney (KI), the lungs (LU), the pericardium (PS), and the heart (HT). The relative ratio of the sum of indicators of total sympathetic activity to parasympathetic activity determines the orientation of the vegetative balance. The numerical result of this correlation is the vegetative coefficient $\mathrm{kV}$ (the autonomic nervous system coefficient), according to which seven levels of functional health dispersion are distinguished today: PAs the zone of significant parasympathetic activity $(\mathrm{kV}$ to $0.75)$; PAe is a zone of expressed parasympathetic activity $(\mathrm{kV} 0.76-0.86)$; FcP is the zone of functional compensation of parasympathetic activity $(\mathrm{kV} 0,87-0,94)$; $\mathrm{VE}$ is the zone of permissible vegetative (functional) equilibrium ( $\mathrm{kV} \mathrm{0,95-1,05);} \mathrm{FcS} \mathrm{is} \mathrm{the} \mathrm{zone} \mathrm{of} \mathrm{functional}$ compensation of sympathetic activity (kV 1.06-1.13); $\mathrm{SAe}$ is a zone of expressed sympathetic activity $(\mathrm{kV}$ $1,14-1,26)$ and SAs is a zone of significant sympathetic activity $(\mathrm{kV}>1,26)$. It is more convenient to use vegetative dispersion (scattering) across critical zones for functional and ecological assessment of environmental factors, i.e the ratio PA (PAs + PAe $)-\mathrm{VE}(\mathrm{FcP}+\mathrm{VE}+$ $\mathrm{FcS})-\mathrm{SA}(\mathrm{SAe}+\mathrm{SAs})$, which are markers of functional health. It is possible to analyze the impact on humans from the received data on the status of functional health of the population of a certain territory and averaged information on the deviation of the autonomic nervous system, both abiotic factors and possible environmental problems of the territory and its degree of ecological disturbance. As a result of research works it was found out that the main characteristic reflecting the negative influence of factors of external and internal environment is the decrease in the number of people examined in the area of functional equilibrium and their increase in the area of parasympathetic activity. According to the criteria we have developed, functional health of people is in the area of conditional norms while $70 \%$ of the population are in the area of vegetative (functional) (VE). An analysis of the obtained data revealed that no age group of men meets these requirements. This indicates a violation of functional and vegetative health and leads to disadaptation of the organism under the influence of changing conditions of the external and internal environment (Table 1).

Table 1

Indicators of functional and ecological expertise

\begin{tabular}{|c|c|c|c|}
\hline Environmental Control & \multicolumn{3}{|c|}{ Vegetative status, \% } \\
\cline { 2 - 4 } Region & PA zone & VE zone & SA zone \\
\hline Functional safety zone - FS & 15 & 70 & 15 \\
\hline $\begin{array}{c}\text { Zone of increased functional } \\
\text { attention - IFA }\end{array}$ & 25 & 50 & 25 \\
\hline $\begin{array}{c}\text { Functional stress development } \\
\text { zone - FSD }\end{array}$ & 30 & 50 & 20 \\
\hline $\begin{array}{c}\text { Functional catastrophe } \\
\text { development zone - FCD }\end{array}$ & 45 & 40 & 15 \\
\hline $\begin{array}{c}\text { Functional Environmental } \\
\text { Disaster Zone - FED }\end{array}$ & 65 & 25 & 10 \\
\hline $\begin{array}{c}\text { Functional protection tension } \\
\text { zone - FPT }\end{array}$ & 10 & 25 & 65 \\
\hline
\end{tabular}


Among the pollutants the greatest attention is paid to radioactive contamination of the environment the only factor controlled to date. More than $60 \%$ of discarded isotopes of transuranium elements and $90 \mathrm{Sr}$ remain in the exclusion zone. The density of radioactive contamination $137 \mathrm{Cs}\left(15 \mathrm{Ki} / \mathrm{km}^{2}\right.$ does not require radiation protection of the population) as the criterion of danger was mistakenly accepted in 1989-1992. This led to an exceeding the standards of contamination of milk and meat which had a corresponding impact on children health. Precipitation of radioactive clouds increased in rainy weather. Therefore, contamination of $137 \mathrm{Cs}, 90 \mathrm{Sr}$ (and other radionuclides) is clearly spotty and may differ. This situation applies even to radiation-free areas.

The surveyed populated areas of Bondurivka village, Katashyn village, Rogizka village, Chervona Grebliya village, the town of Chechelnik, Chechelnyk district in Vinnytsia region belong to the IV radiation control zone. During 1993-1996 we conducted observations to verify the radiation dependence of functional health and the dosimetric certification of settlements.
In the study of functional health of children in the villages Katashin, Rogizka and the town. Chechelnyk of the Chechelnyk district (Cs137 in soil 25,7-12,9$27,1 \mathrm{kB} / \mathrm{m}^{2}$ ) in 1993-1996 revealed that the dispersion of vegetative levels (levels of vegetative equilibrium) in the female and male groups had dynamic identity, though, in the female the group a more pronounced deterioration in the functional health of children was observed (Fig. 1-4).

Our observations in 1993-1994 revealed gender-specific functional health in children. Observations in the female and male groups indicate the relationship among Katashyn, Rogizka and town Chechelnyk of Chechelnyk district, which belong to the 4th zone of radiation state control to the zone of "functional safety" (FS) according to FEE (Fig. 1-2). FEE results of Katashyn, Rogizka and town Chechelnyk of the Chechelnyk district do not coincide with the official dosimetric certification of these settlements.

Our observations in 1995-1996 revealed gender-specific functional health of children. Observations in the female and male groups indicate the relation-

Table 2

Criteria for radiation characteristics of the surveyed settlements (2008)

\begin{tabular}{|c|c|c|c|c|c|c|c|c|}
\hline \multirow{2}{*}{ Region } & \multirow{2}{*}{ Settlement } & \multirow{2}{*}{ Chernobyl zone } & \multicolumn{2}{|c|}{$\mathbf{C s}^{137}\left(\mathbf{k B q} / \mathbf{m}^{\mathbf{2}}\right)$} & \multicolumn{3}{|c|}{$\mathbf{m Z} /$ year by } & \multirow{2}{*}{$*$} \\
\cline { 3 - 8 } & & & Soil & $\mathbf{m i l k}$ & $\mathbf{2 0 0 6}$ & $\mathbf{7 0}$ years & HRC & \\
\hline R-№99(1) & Bondurivka & 4th & 64,0 & 2,2 & 0,20 & 9,2 & 0,03 & + \\
\hline R-№9(2) & Katashyn & 4th & 25,7 & 0,6 & 0,08 & 4,1 & 0,08 & + \\
\hline R-№9(3) & Rogizka & 4th & 12,9 & 1,3 & 0,06 & 2,1 & 0,02 & + \\
\hline R-№9(4) & Chervona Grebliya & 4th & 35,6 & 0,9 & 0,11 & 5,5 & 0,02 & + \\
\hline R-№9(5) & Chechelnyk & 4th & 27,1 & 1,3 & 0,11 & 3,7 & 0,02 & + \\
\hline
\end{tabular}

Note: HRC - human radiation counter; ${ }^{*}$ - compliance of FEE with dosimetric and thyroid dosimetric state radiation control
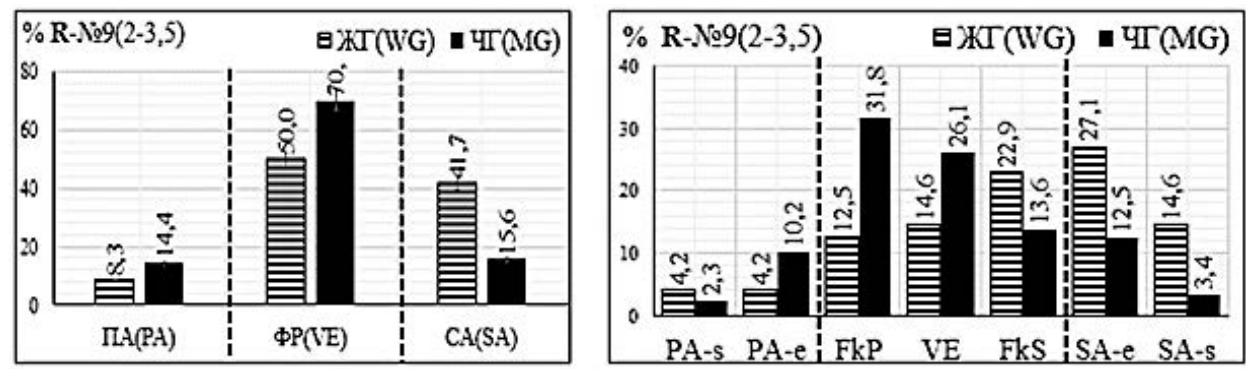

Fig. 1. Critical vegetative zones and levels of vegetative equilibrium of children living in the villages Katashyn, Rogizka and the town Chechelnyk of Chechelnyk district, 1993
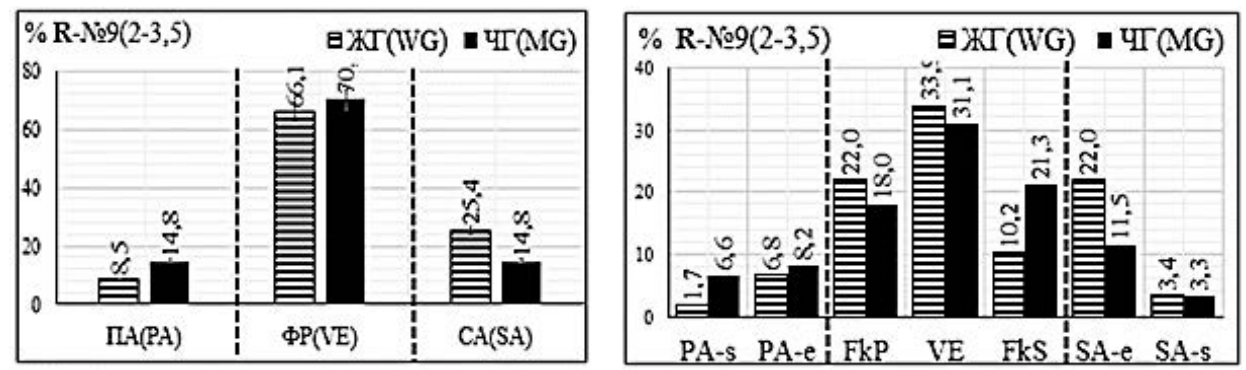

Fig. 2. Critical vegetative zones and levels of vegetative equilibrium of children living in the villages Katashyn, Rogizka and town Chechelnyk of the Chechelnyk district, 1994 
ship of Katashyn, Rogizka and town Chechelnyk of Chechelnyk district to the zone of "the development of functional tension" (FPT) (4th zone of radiation control) in 1995 (Fig. 3) and to the zone of "the development of functional catastrophe" (FCD) (4th zone of radiation control) (fig. 3-4).

FEE results in the villages Katashyn, Rogizka and town Chechelnyk of Chechelnyk district coincide with the official dosimetric certification of these settlements.

1993-1996 observations revealed an increase in parasympathetic dispersion of autonomic levels of children living in the villages Katashyn, Rogizka and town Chechelnyk of Chechelnyk district, which confirms the negative impact of the radiation component on the functional health of children and the deterioration of the state of endoecology due to the accumulation of radioactive isotopes.

In the study of children functional health in the village Bondurivka in Chechelnyk district (Cs137 in soil $64 \mathrm{kB} /$ $\left.\mathrm{m}^{2}\right)$ in 1993 it was found that the dispersion of vegeta- tive levels (levels of vegetative equilibrium) in the female and male groups had dynamic identity, but with the same number of children examined in the functional group $66.7 \%$, in the female group $33.3 \%$ belong to the zone of parasympathetic activity and in the male group $33.3 \%$ belong to the zone of sympathetic activity (Fig. 5).

In the study of functional health of children in the village Bondurivka of Chechelnyk district (Cs137 in soil $64 \mathrm{kB} / \mathrm{m}^{2}$ ) in 1994-1996 it was revealed that the dispersion of vegetative levels (levels of vegetative equilibrium) in the female and male groups had dynamic identity (Fig. 6-7).

Our observations in 1993-1994 revealed gender-specific functional health of children. Observations in the female and male groups indicate the relationship in the village Bondurivka of Chechelnyk district which belong to the 4th zone of radiation state control to the zone of "functional safety" (FS) according to FEE (Fig. 5-6). FEE results in the village Bondurivka of Chechelnyk district do not coincide with the official dosimetric certification of these settlements.
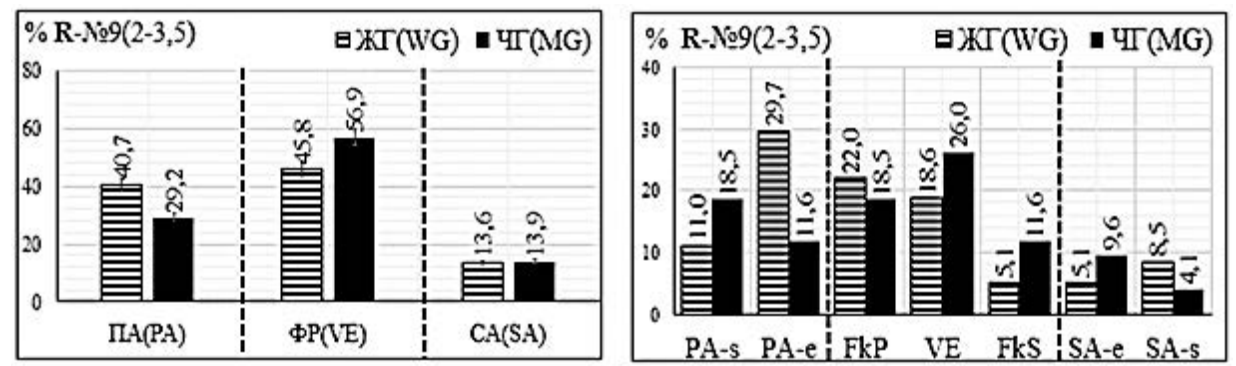

Fig. 3. Critical vegetative zones and levels of vegetative balance of children living in the villages Katashyn, Rogizka and town Chechelnyk of Chechelnyk district, 1995
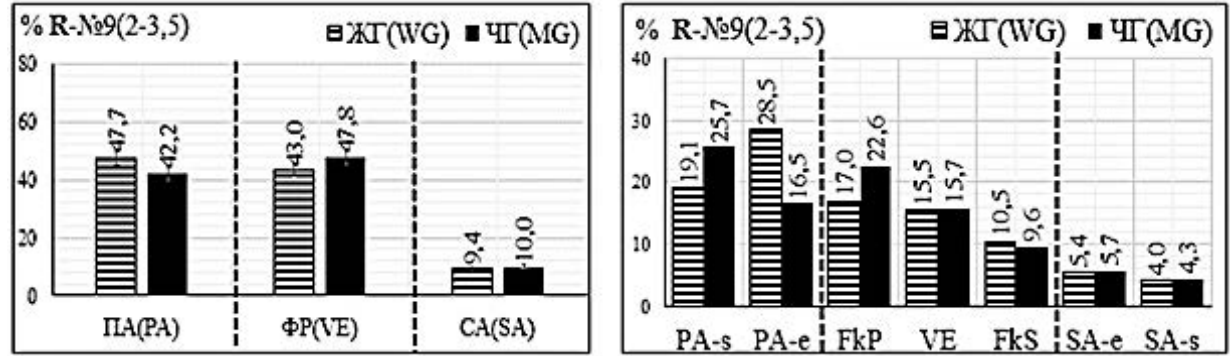

Fig. 4. Critical vegetative zones and levels of the vegetative equilibrium of children living in the villages Katashyn, Rogizka and town Chechelnyk of Chechelnyk district, 1996
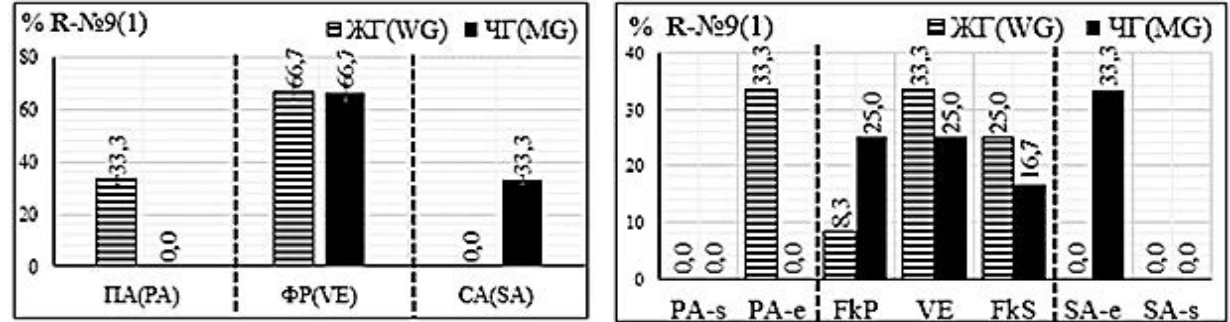

Fig. 5. Critical vegetative zones and levels of vegetative equilibrium of children living in the village Bondurivka of Chechelnyk district, 1993 

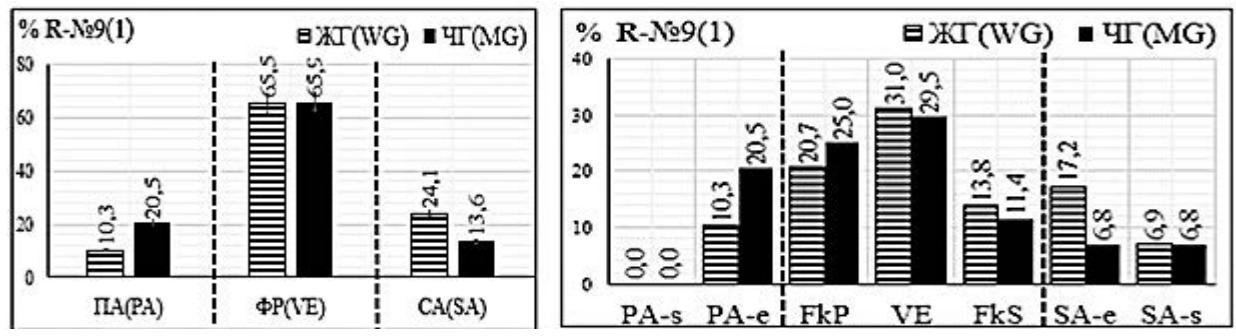

Fig. 6. Critical vegetative zones and levels of vegetative equilibrium of children living in the village Bondurivka in Chechelnyk district, 1994
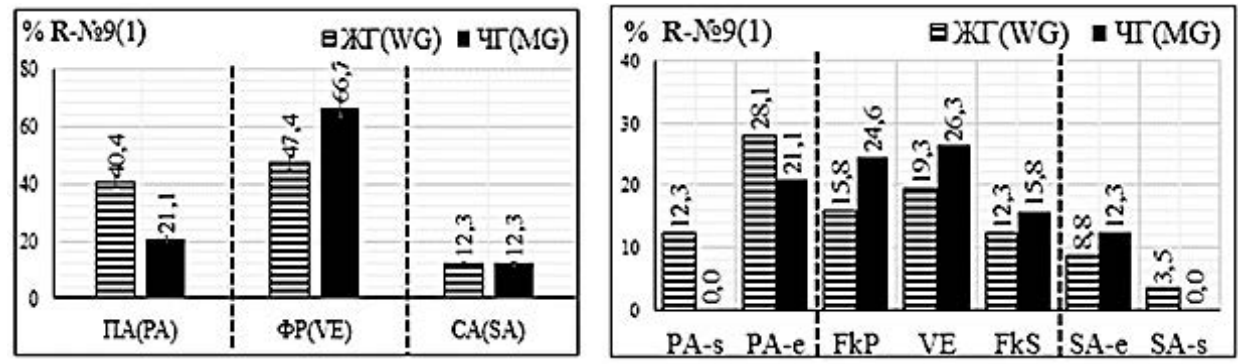

Fig. 7. Critical vegetative zones and levels of vegetative equilibrium of children living in the village Bondurivka in Chechelnyk district, 1996

Our observations in 1996 revealed gender-specific functional health of children. Observations in the female and male groups indicate the relationship in the village Bondurka in Chechelnyk district to the zone of the "increased functional attention" (IFA) (4th radiation control zone) (Fig. 7). FEE results in the village Bondurivka in Chechelnyk district coincides with the official dosimetric certification of these settlements.

Observations of 1993-96 revealed an increase in the parasympathetic dispersion of the vegetative levels of children living in the village Bondurivka in Chechelnyk district which confirms the negative pressure of the radiation component on the functional health of children and the deterioration of the state of endoecology due to the accumulation of radioactive isotopes.
The main findings.

1. Functional vegetative health of children is ecologically dependent. In addition, it is a bioindicator and underlies functional and ecological expertise (FEE) of radiation control regions.

2. Indicators of functional and vegetative health of the pediatric population are the most sensitive bioindicators of radiation (environmental) pollution and require prompt implementation in order to preserve the Gene Pool of Ukraine.

3. Functional vegetative health of children of the surveyed settlements of the Chechelnyk district coincides with the official dosimetric certification of the settlements.

4. Monitoring of the vegetative health of children should become the basis of modern functional medical examination of the pediatric population and supplement state dosimetric and thyroid dosimeter certification of the settlements.

\section{References}

1. Григорьев А.И., Григорьев К.И. Роль неблагоприятных факторов окружающей среды в формировании нарушений адаптации у детей и подростков. Медицинская сестра. 2018. № 7. С. 32-38. DOI: https://doi.org/10.29296/25879979-2018-07-07.

2. Интегральная оценка работоспособности при умственном и физическом труде / под ред. Е. А. Деревянко. Москва : Экономика, 1990. 109 с.

3. Срмішев О.В., Петрук Р.В., Овчинникова Ю.Ю., Костюк В.В. Функціональне здоров'я дітей як екологічний біоіндикатор України (Вінницька, Львівська, Чернігівська області) / за редакцією професора В.Г. Макаца). Вінниця : Наукова ініціатива, 2017. 226 c.

4. Константинова Е.Д., Маслакова Т.А., Шалаумова Ю.В., Вараксин А.Н., Живодеров А.А. Радиоактивное загрязнение территории и адаптационная реакция организма человека. Экология человека. 2019. № 2. C. 4-11. DOI: 10.33396/1728-0869-2019-2-4-11.

5. Макац В.Г., Макац С.Ф., Макац Д.В., Макац Д.В., Петінов Я.П. Вегетативный атлас функционального здоровья детского населения Украины (Винницкая, Львовская, Черниговская области). Том IV. Винница : Нилан- ЛТД, 2013. 496 с.

6. Макац В.Г., Нагайчук В.І., Макац Є.Ф., Срмішев О.В. Невідома китайська голкотерапія (проблеми вегетативного патогенезу). Том IV. Вінниця : Нілан-ЛТД, 2017. 286 с.

7. Макац В.Г., Макац Є.Ф., Макац Д.В., Макац Д.В. Основи функціональної вегетології (невідома китайська голкотерапія). Том V. Вінниця : Нілан ЛТД, 2018. 152 с. 
8. Макац В.Г., Курик М.В., Петрук В.Г., Нагайчук В.І., Єрмішев О.В. Основи функціонально-екологічної експертизи (невідома вегетологія). Том VI. Вінниця : Нілан-ЛТД, 2018. 128 с.

9. Радіологічний стан територій, віднесених до зон радіоактивного забруднення (у розрізі районів) / МНС України у справах захисту населення від наслідків Чорнобильської катастрофи. Київ : ТОВ «Інтелектуальні системи ГЕО», 2008. 49 с.

10. Jänig W. Integrative Action of the Autonomic Nervous System. Neurobiology of Homeostasis. Cambridge : Cambridge University Press, 2008. $636 \mathrm{p}$.

11. Parashar R., Amir M., Pakhare A., Rathi P. Age Related Changes in Autonomic Functions. Journal of Clinical and Diagnostic Research. 2016. No. 10 (3). P. 11-13. DOI: 10.7860/JCDR/2016/16889.7497. 